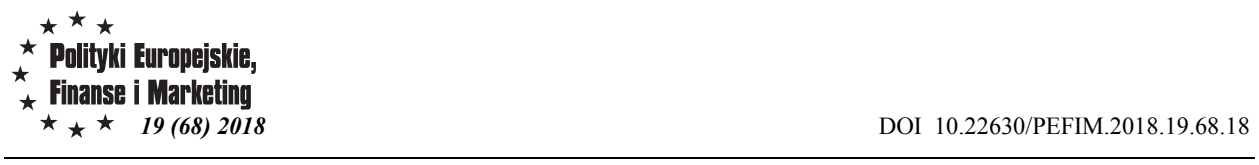

Maciej Pawlowski

Uniwersytet Szczeciński

\title{
Modele dyskryminacyjne w ocenie ryzyka upadłości emitenta obligacji korporacyjnych
}

\section{DISCRIMINATORY MODELS AS AN EVALUATION METHOD OF CORPORATE BOND ISSUERS BANKRUPTCY RISK}

\begin{abstract}
Przedmiotem opracowania jest weryfikacja przydatności wybranych modeli dyskryminacyjnych $w$ ocenie ryzyka upadłości emitenta obligacji korporacyjnych. W artykule omówiono istotę upadtości przedsiębiorstwa jako przedmiotu badań ekonomicznych oraz dokonano charakterystyki wybranych modeli wczesnego ostrzegania. Na podstawie wyselekcjonowanych modeli przeprowadzono badania empiryczne na grupie pięciu celowo dobranych spótek reprezentujacych emitentów obligacji korporacyjnych notowanych na rynku Catalyst. Przeprowadzone analizy skłonity do wniosku, że największa skutecznościa w zakresie identyfikacji ryzyka upadłości emitenta obligacji korporacyjnych charakteryzowat się model B. Prusaka.
\end{abstract}

Słowa kluczowe: modele dyskryminacyjne, upadłość przedsiębiorstw, obligacje korporacyjne.

\section{Wprowadzenie}

Dotychczasowy dorobek naukowy, jak również doświadczenia praktyki gospodarczej, dostarczają wielu różnorodnych metod wczesnego ostrzegania przed upadłością przedsiębiorstw. Wśród nich wymienić można między innymi: tradycyjną analizę finansową przedsiębiorstwa opartą na analizie wskaźnikowej, systemy eksperckie, modele optymalizacyjne, analizę przetrwania, sztuczne sieci neuronowe, czy metody ekonometryczne - liniowa i kwadratowa wielowymiarowa analiza dyskryminacyjna oraz analizy logitowe ${ }^{1}$. Bogaty i nieustannie rozbudowywany wachlarz metod analitycznych służących predykcji upadłości przedsiębiorstwa wynika z potrzeby identyfikacji symptomów pogarszającej się sytuacji finansowej danej jednostki. Konsekwencje upadłości przedsiębiorstwa obserwowane są bowiem nie tylko po stronie jego właścicieli, lecz również wpływają na sytuację jednostek powiązanych z danym podmiotem - pracowników, dostawców, inwestorów i wierzycieli, administracji publicznej i instytucji finansowych. Treść niniejszego opracowania poświęcono modelom zbudowanym na podstawie wielowymiarowej analizy dyskryminacyjnej, a celem prowadzonych analiz jest empiryczna weryfikacja skuteczności wybranych modeli wczesnego ostrzegania w procesie predykcji upadłości

\footnotetext{
1 Prusak: Nowoczesne metody prognozowania zagrożenia finansowego przedsiębiorstw. Difin, Warszawa 2005, s. 46 i nast.
} 
emitenta obligacji korporacyjnych. Badania przeprowadzono przy wykorzystaniu sześciu wybranych modeli analizy dyskryminacyjnej, których wartość ustalono dla grupy pięciu przedsiębiorstw reprezentujących grono emitentów obligacji korporacyjnych postawionych w stan upadłości ${ }^{2}$ (dobór obiektów badawczych miał charakter celowy, a kryteria służące selekcji jednostek zostały opisane w dalszej części opracowania).

Znaczenie rozważanego problemu badawczego przejawia się w próbie wskazania, który $\mathrm{z}$ analizowanych modeli identyfikuje ryzyko upadłości emitenta obligacji korporacyjnych $\mathrm{z}$ największą skutecznością i w konsekwencji - może znaleźć praktyczne zastosowanie. Zagadnienie to jest szczególnie istotne w perspektywie nikłego wykorzystania oznaczeń ratingowych w procesach emisji długu realizowanych w warunkach polskiego rynku obligacji. Modele dyskryminacyjne - o ile charakteryzowałby się skutecznością - mógłby stanowić element oceny ryzyka inwestycyjnego, pełniąc tym samym kryterium oceny i klasyfikacji instrumentów dłużnych.

\section{Ryzyko upadłości emitenta obligacji korporacyjnych na tle teorii upadłości przedsiębiorstwa}

Upadłość przedsiębiorstwa jest cechą współczesnej gospodarki i zagadnieniem o charakterze interdyscyplinarnym, stanowiącym przedmiot badań wielu dyscyplin naukowych. Spośród licznych podjeść interpretacyjnych dotyczących definicji oraz zakresu pojęcia upadłość przedsiębiorstwa na szczególną uwagę zasługują dwa wzajemnie powiązane i przenikające się nurty, umiejscowione w źródłach obowiązującego prawa oraz w dziedzinie nauk ekonomicznych.

W aspekcie prawnym upadłość przedsiębiorstwa jest procedurą wszczynaną w przypadku niewypłacalności jednostki, a więc w sytuacji, w której przedsiębiorstwo nie jest zdolne do regulowania swoich zobowiązań pieniężnych $\mathrm{w}$ chwili ich prawnej wymagalności ${ }^{3}$. W odniesieniu do osób prawnych lub jednostek organizacyjnych nieposiadających osobowości prawnej za przesłankę niewypłacalności uznaje się także sytuację, w której łączna kwota zobowiązań pieniężnych przekracza bilansową wartość majątku jednostki ${ }^{4}$. W kategoriach prawnych upadłość przedsiębiorstwa ogłaszana jest przez sąd i w swej istocie odnosi się do ${ }^{5}$ :

\footnotetext{
2 W badaniu zrezygnowano $\mathrm{z}$ ustalenia wartości wyselekcjonowanych modeli dyskryminacyjnych dla jednostek reprezentujących grono emitentów obligacji korporacyjnych, którzy nie ogłosili upadłości. Dobór jednostek ,zdrowych” jako punktu odniesienia wymagałby bowiem odrębnej metodyki służącej klasyfikacji obiektów badawczych z jednoczesną identyfikacją kryteriów podziału na jednostki o dobrej, złej lub pogarszającej się kondycji finansowej. Z kolei odwołanie się w badaniu wyłącznie do przedsiębiorstw uznawanych za jednostki o najlepszych wynikach spowodowałoby obciążenie osiągniętych rezultatów brakiem spółek o przeciętnej kondycji finansowej, a więc tych, które teoretycznie mogłyby wykazywać symptomy przyszłej upadłości.

Gołębiowski, Żywno: Weryfikacja skuteczności modeli dyskryminacyjnych na przykładzie wybranych spółek giełdowych. „Współczesna Ekonomia” nr 3 (7), Warszawa 2008, s. 32.

${ }_{3}^{3}$ art. 10 Ustawa z dnia 28 lutego 2003 r. Prawo upadłościowe, Dz.U. 2003, nr 60, poz. 535 z póżn. zm.

${ }^{4}$ Ibidem.

${ }^{5}$ Hamrol, Chodakowski: Prognozowanie zagrożenia finansowego przedsiębiorstwa. Wartość predykcyjna polskich modeli analizy dyskryminacyjnej. Badania Operacyjne i Decyzje nr 3, Oficyna Wydawnicza Politechniki Wrocławskiej, Wrocław 2008, s. 18.
} 
- pozbawienia osoby prowadzącej przedsiębiorstwo prawa i możliwości zarządzania oraz dysponowania majątkiem na rzecz wyznaczonego przez sąd syndyka masy upadłościowej, którego celem jest przeprowadzenie postępowania zmierzającego do zaspokojenia roszczeń wszystkich wierzycieli upadłego przedsiębiorstwa;

- instytucji, która ma zaprzestać narastaniu długów, lagodzić ich skutki i zapewnić wierzycielom równy udział $\mathrm{w}$ zaspokajaniu ich interesów z majątku dłużnika, w konsekwencji prowadząc do eliminacji z rynku słabych podmiotów gospodarczych;

- przymusowego wykonania zobowiązań w przypadku zaprzestania obsługi długu, a także w sytuacji, gdy majątek nie wystarcza na ich pokrycie;

- egzekucji uniwersalnej prowadzonej na rzecz wszystkich wierzycieli dłużnika, ze wszystkich składników jego majątku jednocześnie.

$\mathrm{W}$ ujęciu ekonomicznym pojęcie upadtości przedsiębiorstwa jest trudne do jednoznacznego zdefiniowania, bowiem nie funkcjonuje ścisłe, jednoznaczne i powszechnie obowiązujące ujęcie analizowanego zagadnienia ${ }^{6}$. Jak wskazuje W. Rogowski upadtość przedsiębiorstwa nie jest terminem oczywistym i stanowi on jedynie agregat pojęciowy dla podzbioru sytuacji, w efekcie których przedsiębiorstwo zaprzestaje prowadzenia działalności gospodarczej. W konsekwencji upadłość przedsiębiorstwa odnosi się do stanu?

- niewypłacalności jednostki gospodarczej, rozumianej jako brak zdolności do uregulowania wymagalnych zobowiązań przy wykorzystaniu posiadanych środków finansowych lub tych, które można pozyskać $\mathrm{z}$ upłynnienia majątku;

- bankructwa, czyli sytuacji, w której wartość zobowiązań przekracza rynkową wartość majątku dłużnika. O bankructwie przesądza także brak możliwości kontynuowania prowadzonej działalności gospodarczej bez pomocy z zewnątrz, która zapewniłaby jednostce: wzrost rentowność działalności, poprawę poziomu zyskowności, wypłacalność czy możliwość konkurowania na rynku (a w konsekwencji kontynuowanie działalności gospodarczej);

- utraty zdolności płatniczej, czyli trwałej niezdolność przedsiębiorstwa do spłacenia zaciągniętych zobowiązań (ogółem);

- kryzysu finansowego i organizacyjnego, który zazwyczaj poprzedzony jest błędną alokacją kapitału (realizacją nieopłacalnych projektów biznesowych), której negatywne skutki przejawiają się w nieosiaganiu marży na pokrycie kosztów stałych oraz docelowych zysków, a w dalszej kolejności niezadowalającym (bądź ujemnym) poziomem zyskowności sprzedaży, niską rentownością zasobów (majątku i kapitałów), niezdolnością podmiotu do regulowania najbardziej wymagalnych zobowiązań (utrata płynności finansowej).

\footnotetext{
${ }^{6}$ Kowalczyk: Przyczyny upadłości firm agrobiznesu [w:] Meandry upadłości przedsiębiorstw. Klęska czy druga szansa?, Oficyna Wydawnicza Szkoły Głównej Handlowej, Warszawa 2009, s. 108.

7 Rogowski: Przyczyny upadłości przedsiębiorstwa w Polsce. Biuletyn Polskiego Towarzystwa Ekonomicznego nr 1 (68), Warszawa 2015, s. 41-43.
} 
Konfrontacja przytoczonych spostrzeżeń daje podstawy by twierdzić, iż ekonomiczny aspekt upadłości przedsiębiorstwa obejmuje szerszy zakres zagadnień. W ujęciu prawnym treść objaśnianego pojęcia koncentruje się na dwóch aspektach sytuacji przedsiębiorstwa dotyczących: trwałej utraty zdolności przedsiębiorstwa do obsługi zadłużenia oraz kwestii wartości zobowiązań, których wielkość nie odnajduje odzwierciedlenia (zabezpieczenia) w majątku jednostki. Natomiast w ujęciu ekonomicznym problem upadłości przedsiębiorstwa rozpatrywany jest przez pryzmat przesłanek determinujących stan niewypłacalności. Analizą obejmuje się kwestię osiąganych wyników finansowych oraz czynników charakteryzujących sytuację finansową przedsiębiorstwa, takich jak: poziom płynności finansowej, stopę rentowności czy strukturę kapitału (lub szerzej - strukturę źródeł finansowania). Ponadto rozpatrując zagadnienie upadłości przedsiębiorstwa w powyższym układzie dostrzec także można, iż upadłość przedsiębiorstwa w sensie ekonomicznym poprzedza upadłość jednostki rozumianą $\mathrm{w}$ jej prawnym aspekcie - zaburzenia obserwowane $\mathrm{w}$ finansowej sferze działalności jednostki gospodarczej przekładają się bowiem na stan jej niewypłacalności, prowadząc w konsekwencji do upadłości (rozumianej w znaczeniu prawnym).

Rozpatrując zatem problem ryzyka upadłości emitenta obligacji korporacyjnych wyodrębnić należy jego ekonomiczny i prawny charakter.

W ujęciu ekonomicznym ryzyko upadłości emitenta obligacji korporacyjnych dotyczy sytuacji, w której emitent długu narażony jest na utratę zdolności do regulowania bieżących lub/i przyszłych zobowiązań względem grona wierzycieli (obligatariuszy). Tak rozumiana niewypłacalność emitenta dotyczy możliwości zaprzestania obsługi wszelkich świadczeń deklarowanych przez niego w ramach emisji obligacji, a w szczególności wypłaty okresowych płatności odsetkowych oraz wykupu obligacji w terminie ich zapadalności. Analizowana kategoria ryzyka obejmuje liczną grupę zjawisk ${ }^{8}$, które w efekcie prowadzą do zakłócenia przepływów pieniężnych zwiększenia strony wydatków bądź zmniejszenia spodziewanych wpływów gotówkowych $^{9}$ - lub zmniejszają wartość majątku posiadanego przez emitenta obligacji. Zmiana sytuacji finansowej w skrajnym przypadku prowadzić może do całkowitej utraty zdolności płatniczej, zaniechania obsługi długu oraz bankructwa przedsiębiorstwa. W literaturze ekonomicznej pisze się wówczas o: ryzyku kredytowym, ryzyku niedotrzymania warunków, ryzyku nieściaggalności długu lub ryzyku upadłości (traktując wymienione pojęcia jako synonimy).

W sensie prawnym ryzyko upadłości emitenta obligacji korporacyjnych jest wypadkową czynników składających się na ekonomiczną definicję analizowanego zagadnienia. Przejawia się ono $\mathrm{z}$ chwilą utraty zdolności emitenta do terminowego regulowania zobowiązań podjętych w ramach emisji długu. W świetle obowiązującego prawa jeżeli emitent nie wypełni w terminie całości lub części świadczeń inkorporowanych treścią obligacji, wówczas instrumenty te podlegają natychmiastowemu wykupowi na każdorazowe żądanie obligatariusza. Materializacja

\footnotetext{
${ }^{8}$ Pełnej analizy czynników i rodzajów ryzyka upadłości przedsiębiorstwa dostarcza praca: Korol: Systemy ostrzegania przedsiębiorstw przed ryzykiem upadłości. Oficyna Wydawnicza Wolters Kluwer Polska, Warszawa 2010, s. 62-79.

${ }^{9}$ Wieczorek-Kosmala: Aplikacja instrumentów alternatywnego finansowania ryzyka (ARF) - nowy wymiar retencji ryzyka w przedsiębiorstwie [w:] Ubezpieczenia gospodarcze i społeczne. Wybrane zagadnienia ekonomiczne. Oficyna Wydawnicza Wolters Kluwer Polska, Warszawa 2011, s 26.
} 
ryzyka upadłości emitenta obligacji nieuchronnie prowadzi do procedury zaspokojenia wierzycieli ujętej w prawie upadłościowym ${ }^{10}$, wedle którego kapitał pochodzący z emisji obligacji niezabezpieczonych zaspokajany jest $\mathrm{w}$ ramach kategorii pierwszej.

Warto w tym miejscu nadmienić, że dochodzenie roszczeń w przypadku obligacji zabezpieczonych na majątku emitenta przebiega w odmienny sposób. Przedmiot zabezpieczenia praw inkorporowanych treścią obligacji tworzy osobną masę upadłościową, dedykowaną $\mathrm{w}$ pierwszej kolejności zaspokojeniu roszczeń obligatariuszy. Uprzywilejowana pozycja prawna wierzycieli dotyczy jednak wyłącznie wartości składników majątku, na których ustanowiono zabezpieczenie. W sytuacji, gdy upłynnienie aktywów zabezpieczających interes obligatariuszy nie pokryje w pełni zobowiązań emitenta wobec tej grupy podmiotów, wówczas wartość niezaspokojonych należności będzie realizowana z ogólnej masy upadłościowej (zgodnie z przewidzianą prawem kolejnościa ich realizacji). Natomiast w przypadku, gdy rynkowa wartość zabezpieczenia przekracza sumę zobowiązań, nadwyżkę funduszy zalicza się na poczet ogólnej masy upadłości ${ }^{11}$.

\section{Wybrane modele dyskryminacyjne prognozowania ryzyka upadłości przedsiębiorstwa}

W licznych opracowaniach naukowych podnosi się tezę, iż upadłość przedsiębiorstwa nie jest zjawiskiem nagłym a niektóre symptomy informujące o zagrożeniu kontynuacji działalności jednostki mogą zostać wykryte $\mathrm{z}$ odpowiednim wyprzedzeniem, dając szansę podjęcia działań naprawczych ${ }^{12}$. Twierdzenie to stanowi przesłankę dla ekonomicznej analizy ryzyka upadłości przedsiębiorstwa przy wykorzystaniu modeli opartych na wielowymiarowej analizie dyskryminacyjnej. Modele te charakteryzują się wysoką sprawnością i mają znaczną przewagę nad modelami jednowymiarowymi, gdyż uwzględniają jednoczesny wpływ wielu zmiennych na badane zjawisko - ryzyko upadłości przedsiębiorstwa. Pewną przeciwwagę dla prostoty omawianej metody oraz wspomnianych zalet stanowi fakt, iż $\mathrm{w}$ swej istocie zupełnie pomijają one specyficzne sytuacje i zjawiska towarzyszące działalności badanego obiektu. Modele analizy dyskryminacyjnej bazują bowiem na odpowiednio wyselekcjonowanych wskaźnikach finansowych oraz nadanym im wagach, nie uwzględniając takich aspektów jak: szanse rozwojowe badanego przedsiębiorstwa, stan koniunktury gospodarczej, pozycja konkurencyjna jednostki czy kompetencje i doświadczenia zarządu. Wobec powyższego krytyka analizowanych metod ogniskuje się na: (1) zbyt wąskim spektrum czynników (aspektów) determinujących sytuację finansowa jednostek gospodarczych oraz (2) przypisywaniu nadmiernej roli jednemu ze wskaźników ujętych w modelu (w drodze nadania wag). Dodatkowo, przyjęte wagi odzwierciedlają specyfikę lokalnych (krajowych) warunków funkcjonowania przedsiębiorstw i ich otoczenia, co utrudnia mechaniczne przenoszenie modeli

\footnotetext{
${ }^{10}$ Ustawa z dnia 28 lutego 2003 r. Prawo upadłościowe, Dz.U. 2003, nr 60, poz. 535 z póżn. zm.

${ }^{11}$ Pawłowski: Rynek obligacji korporacyjnych w Polsce. Uwarunkowania i perspektywy rozwoju. Cedewu, Warszawa 2015, s. 100.

${ }^{12}$ Zielińska-Chmielewska: Zastosowanie analizy dyskryminacyjnej do oceny zagrożenia upadłością polskich przedsiębiorstw przetwórstwa mięsnego. Studia Oeconomica Posnaniensia vol. 3, no. 4, Wydawnictwo Uniwersytetu Ekonomicznego w Poznaniu, Poznań 2015, s. 142.
} 
opracowanych $\mathrm{w}$ jednych systemach gospodarczych do drugich - wykorzystanie zagranicznych modeli dyskryminacyjnych w identyfikacji ryzyka upadłości przedsiębiorstw funkcjonujących $\mathrm{w}$ warunkach polskiej gospodarki jest niepoprawne metodycznie i na ogół nie przynosi satysfakcjonujących rezultatów ${ }^{13}$.

Dla potrzeb niniejszego opracowania analizą objęto 6 wybranych modeli dyskryminacyjnych służących ocenie ryzyka upadłości przedsiębiorstwa:

1) Model D. Hadasik:

$$
\begin{gathered}
\mathrm{Z}_{\mathrm{H}}=2,36261+0,365425 \mathrm{~W}_{1}-0,765526 \mathrm{~W}_{2}-2,40435 \mathrm{~W}_{3}+1,59079 \mathrm{~W}_{4} \\
+0,00230258 \mathrm{~W}_{5}-0,0127826 \mathrm{~W}_{6}
\end{gathered}
$$

gdzie:

$\mathrm{W} 1=$ aktywa obrotowe $/$ zobowiązania krótkoterminowe

$\mathrm{W} 2=$ (aktywa obrotowe - zapasy) $/$ zobowiązania krótkoterminowe

$\mathrm{W} 3=$ zobowiązania ogółem / suma bilansowa

$\mathrm{W} 4=$ kapitał obrotowy netto $/$ suma bilansowa

$\mathrm{W} 5=($ należności $* 365) /$ przychody ze sprzedaży

W6 $=($ zapasy $* 365) /$ przychody ze sprzedaży

Wartość graniczna rozdzielająca obiekty zagrożone upadłością od jednostek o dobrej kondycji finansowej wynosi $-0,374345^{14}$.

2) Model E. Mączyńskiej i M. Zawadzkiego:

gdzie:

$\mathrm{W} 1=\quad($ zysk brutto + amortyzacja $) /$ zobowiązania ogółem

$\mathrm{W} 2=$ suma bilansowa / zobowiązania ogółem

$\mathrm{W} 3=$ zysk brutto / suma bilansowa

$\mathrm{W} 4=$ zysk brutto $/$ przychody ze sprzedaży

$\mathrm{W} 5=$ zapasy $/$ przychody ze sprzedaży

W6 = przychody ze sprzedaży / suma bilansowa

Klasyfikacja i ocena badanych obiektów przebiega zgodnie $\mathrm{z}$ poniższymi założeniami ${ }^{15}$ :

- $\quad \mathrm{Z}_{\mathrm{MZ}}<0$ - przedsiębiorstwo jest zagrożone upadłością

- $\quad \mathrm{Z}_{\mathrm{MZ}}=0-$ wartość graniczna

- $\quad 0<\mathrm{Z}_{\mathrm{MZ}}<1$ - przedsiębiorstwo charakteryzuje się słabą kondycją finansową, ale nie zagrożone upadłością

- $\quad 1<\mathrm{Z}_{\mathrm{MZ}}<2$ - przedsiębiorstwo charakteryzuje się relatywnie dobrą sytuacja finansowa,

- $\mathrm{Z}_{\mathrm{MZ}}>2$ - przedsiębiorstwo charakteryzuje się bardzo dobrą sytuacja finansową.

\footnotetext{
${ }^{13}$ Mączyńska, Zawadzki: Dyskryminacyjne modele predykcji upadłości przedsiębiorstw, „Ekonomista” nr 2/2006, s. 211 i nast.

${ }^{14}$ Hadasik: Upadłość przedsiębiorstw w Polsce. Metody jej prognozowania. Zeszyty Naukowe Seria II: Prace habilitacyjne, Zeszyt 153, Wydawnictwo Akademii Ekonomicznej w Poznaniu, Poznań 1998, s. 157.

15 Jagiełł: Analiza dyskryminacyjna i regresja logistyczna w procesie oceny zdolności kredytowej przedsiębiorstw. Materiały i Studia, Zeszyt 286, Narodowy Bank Polski, Warszawa 2013, s. 33.
} 
3) Model D. Wierzby:

$$
\mathrm{Z}_{\mathrm{W}}=3,26 \mathrm{~W}_{1}+2,16 \mathrm{~W}_{2}+0,3 \mathrm{~W}_{3}+0,69 \mathrm{~W}_{4}
$$

$\mathrm{W} 1=\quad($ zysk z działalności operacyjnej - amortyzacja $) /$ suma bilansowa

$\mathrm{W} 2=$ (zysk z działalności operacyjnej - amortyzacja) / przychody ze sprzedaży

$\mathrm{W} 3=$ aktywa obrotowe / zobowiazzania ogółem

$\mathrm{W} 4=$ kapitał obrotowy netto / suma bilansowa

Przedsiębiorstwa, dla których oszacowana wartość funkcji kształtuje się powyżej zera znajdują się w dobrej kondycji finansowej. Natomiast jednostki dla których rezultat badania daje wynik ujemny narażone są na ryzyko upadłości (wartość graniczna $=0)^{16}$.

4) Model poznański:

$\mathrm{W} 1=\quad$ zysk netto / aktywa ogółem

$\mathrm{W} 2=($ aktywa obrotowe - zapasy $) /$ zobowiązania krótkoterminowe

$\mathrm{W} 3=$ kapitał stały / aktywa ogółem

$\mathrm{W} 4=$ wynik finansowy ze sprzedaży / przychody ze sprzedaży

Wartość graniczna dla modelu wynosi $0^{17}$.

5) Model B. Prusaka:

$\mathrm{W} 1=\quad$ zysk z działalności operacyjnej / suma bilansowa średnia $\mathrm{w}$ roku

$\mathrm{W} 2=$ koszty operacyjne (bez pozostałych kosztów operacyjnych) / zobowiązania krótkoterminowe średnie w roku (bez funduszy specjalnych i krótkoterminowych zobowiązań finansowych)

$\mathrm{W} 3$ = aktywa obrotowe / zobowiązania krótkoterminowe

$\mathrm{W} 4=$ zysk z działalności operacyjnej / przychody netto ze sprzedaży

Wielkością rozgraniczająca podmioty o dobrej kondycji finansowej od jednostek zagrożonych upadłością jest wartość $-0,13$. Ponadto autor modelu zdefiniował tzw. szarą strefę, czyli obszar w którym trudno jest jednoznacznie rozstrzygnąć jaką sytuacją finansową charakteryzuje się badany obiekt. Szara strefa mieści się w przedziale $(<-$ $0,13 ; 0,65>)^{18}$.

6) Model E. Altmana ${ }^{19}$ :

${ }^{16}$ Wierzba: Wczesne wykrywanie przedsiębiorstw zagrożonych upadłością na podstawie wskaźników finansowych. Zeszyty Naukowe nr 9, Wydawnictwo Wyższej Szkoły Ekonomiczno-Informacyjnej w Warszawie, Warszawa 2000, s. 79 i nast.

${ }^{17}$ Hamrol, Chodakowski: Prognozowanie zagrożenia finansowego przedsiębiorstwa. Wartość predykcyjna polskich modeli analizy dyskryminacyjnej. Badania Operacyjne i Decyzje $\mathrm{nr}$ 3, Oficyna Wydawnicza Politechniki Wrocławskiej, Wrocław 2008, s. 22.

${ }^{18}$ Prusak: Nowoczesne metody prognozowania zagrożenia finansowego przedsiębiorstw. Difin, Warszawa 2005, s. $149-155$.

${ }_{19}$ Wbrew wcześniejszym uwagom dotyczącym ograniczonych możliwości wykorzystania modeli zagranicznych w szacowaniu ryzyka upadłości krajowych przedsiębiorstw, w ramach badania uwzględniono jeden z modeli Altmana - tzw. Emerging Market Score (EMS). Przesłanką wykorzystania metody EMS jest fakt, iż została ona opracowana dla potrzeb diagnostyki ryzyka upadłości przedsiębiorstw funkcjonujących na rynkach wschodzących, a więc rynków mniej stabilnych i słabiej rozwiniętych aniżeli gospodarka Stanów Zjednoczonych. 


$$
\mathrm{Z}_{\mathrm{EMS}}=3,25+6,56 \mathrm{~W}_{1}+3,26 \mathrm{~W}_{2}+6,72 \mathrm{~W}_{3}+1,05 \mathrm{~W}_{4}
$$

$\mathrm{W} 1=$ kapitał obrotowy netto / suma bilansowa

$\mathrm{W} 2=$ zysk zatrzymany / suma bilansowa

$\mathrm{W} 3=$ zysk przed zapłatą odsetek i podatków (EBIT) / suma bilansowa

$\mathrm{W} 4=$ kapitał własny (wartość księgowa) / zobowiązania ogółem

Przedsiębiorstwa, dla których model EMS przyjmuje wielkości niższe niż 4.15 to podmioty zagrożone upadłością (im wielkość bliższa zeru, tym ryzyko upadłości jest większe). Jednostki, w przypadku których wynik modelu mieści się w przedziale (4.15; 5.85) to przedsiębiorstwa klasyfikowane w szarej strefie. Natomiast podmioty o dobrej kondycji finansowej to te, dla których model EMS przyjmuje wielkości większe od $5.85^{2021}$.

\section{Identyfikacja ryzyka upadłości emitentów obligacji korporacyjnych przy wykorzystaniu modeli dyskryminacyjnych}

Weryfikację modeli dyskryminacyjnych przeprowadzono na grupie 5 przedsiębiorstw reprezentujących grono emitentów obligacji korporacyjnych. Dobór badanych obiektów miał charakter celowy a ich skromną liczebność uzasadniają dwie przesłanki. Po pierwsze, zgodnie z przedmiotem prowadzonych analiz przedsiębiorstwa wyselekcjonowane do badań musiały charakteryzować się dwoma cechami jednocześnie - wykazywać status emitenta obligacji korporacyjnych oraz udostępniać do publicznej wiadomości sprawozdania finansowe (stanowiące materiał źródłowy dla przeprowadzenia stosownych obliczeń). Drugim kryterium towarzyszącym doborowi jednostek badawczych była kwestia wyselekcjonowania z rynku tych podmiotów, które zostały postawione w stan upadłości. W konsekwencji powyższego jednostki spełniające przyjęte kryteria i stanowiące obiekt badań reprezentowały emitentów obligacji korporacyjnych notowanych na rynku Catalyst ${ }^{22}$.

\footnotetext{
${ }^{20}$ Altman, Hotchkiss: Corporate Financial Distress and Bankruptcy. J. Wiley \& Sons, Inc. Hoboken, New Jersey 2006, s. 268.

${ }^{21}$ Wyznaczone dla modelu EMS wielkości służące klasyfikacji badanych obiektów korespondują ze skalą ratingu towarzyszącego ocenie ryzyka kredytowego obligacji notowanych na amerykańskim rynku finansowym. Wielkością rozgraniczającą rating inwestycyjny od ratingu spekulacyjnego jest 5.25 (rating BB), stąd też w literaturze przedmiotu spotkać można alternatywne sformułowanie wielkości granicznych analizowanego modelu:

- ZEMS < 5.25 - przedsiębiorstwo wykazuje symptomy upadłości (im wielkość niższa, tym ryzyko upadłości większe)

- ZEMS > 5.25 - przedsiębiorstwo nie wykazuje przesłanek upadłości (im wielkość wyższa, tym kondycja finansowa badanego podmiotu jest lepsza).

Powiązanie wyników modelu EMS ze skalą ratingu zaprezentowano w pracy: Altman, Hotchkiss: Corporate Financial Distress and Bankruptcy. J. Wiley \& Sons, Inc. Hoboken, New Jersey 2006, s. 268.

${ }^{22} \mathrm{Nie}$ ma praktycznej możliwości przeprowadzenia diagnostyki w przypadku przedsiębiorstw, których oferta obligacji nie została wprowadzona do zorganizowanego systemu obrotu - rynku Catalyst, charakteryzującego się transparentnością systemu transakcyjnego oraz stosowanymi obowiązkami informacyjnymi. Emitenci spoza rynku zorganizowanego nie są bowiem zobowiązani do upubliczniania dokumentacji finansowej, niezbędnej dla szacowania wartości modeli dyskryminacyjnych. Co więcej - istnieje bariera w identyfikacji emitentów funkcjonujących na rynku zorganizowanym (szczególnie w odniesieniu do jednostek, w stosunku do których ogłoszono upadłość).
} 
Zakres czasowy badań stanowi wypadkową dostępności danych finansowych oraz podjętej próby standaryzacji (ujednolicenia) przedziału czasowego dla jakiego dokonano obliczeń. Analizą objęto okres czterech lub pięciu lat przed ogłoszeniem upadłości (lub złożeniem wniosku o upadłość). Czteroletni okres analizy dotyczy spółek e-Kancelaria i Kopahaus (lata 2011-2014), zaś w przypadku pozostałych trzech jednostek przyjęty przedział analizy to okres pięcioletni (2011-2015).

Zbiorcze zestawienie wyników badań nad praktycznymi możliwościami zastosowania modeli dyskryminacyjnych w ocenie ryzyka upadłości emitentów obligacji korporacyjnych prezentuje tabela 1 .

Tabela 1. Wartości modeli dyskryminacyjnych ustalone dla emitentów obligacji korporacyjnych objętych badaniem

\begin{tabular}{|c|c|c|c|c|c|}
\hline Spółka Rok & 2011 & 2012 & 2013 & 2014 & 2015 \\
\hline e-Kancelaria & 0,413 & 0,392 & 0,431 & 0,490 & \\
\hline GC Investment & $-2,658$ & $-4,342$ & $-3,114$ & $-14,937$ & $-138,775$ \\
\hline Kopahaus & $-0,796$ & 0,425 & 1,037 & 1,607 & \\
\hline PCZ & 1,839 & 1,365 & 1,351 & 1,400 & 1,153 \\
\hline Uboat-Line SA & 1,350 & 1,287 & 0,932 & 1,272 & $-1,759$ \\
\hline \multicolumn{6}{|c|}{ MODEL E. MĄCZYŃSKIEJ I M. ZAWADZKIEGO } \\
\hline $\begin{array}{l}\text { Rok } \\
\text { Spółka }\end{array}$ & 2011 & 2012 & 2013 & 2014 & 2015 \\
\hline e-Kancelaria & 0,601 & 3,174 & 2,255 & 1,956 & \\
\hline GC Investment & 1,696 & 1,381 & 0,644 & $-9,116$ & $-234,409$ \\
\hline Kopahaus & 2,814 & 4,389 & 2,196 & 3,634 & \\
\hline PCZ & 3,913 & 3,547 & 3,122 & 3,344 & 1,785 \\
\hline Uboat-Line SA & 0,457 & 2,972 & 1,954 & 0,967 & $-4,335$ \\
\hline \multicolumn{6}{|c|}{ MODEL D. WIERZBY } \\
\hline $\begin{array}{l}\text { Rok } \\
\text { Spółka }\end{array}$ & 2011 & 2012 & 2013 & 2014 & 2015 \\
\hline e-Kancelaria & 0,812 & 2,385 & 2,993 & 2,531 & \\
\hline GC Investment & 1,725 & 1,344 & 0,674 & $-1,237$ & $-70,724$ \\
\hline Kopahaus & 0,851 & 1,661 & 0,871 & 1,562 & \\
\hline $\mathrm{PCZ}$ & 0,840 & 1,129 & 1,291 & 0,925 & 1,050 \\
\hline Uboat-Line SA & 0,492 & 1,364 & 1,101 & 0,842 & $-3,729$ \\
\hline \multicolumn{6}{|c|}{ MODEL POZNAŃSKI } \\
\hline $\begin{array}{l}\text { Rok } \\
\text { Spółka }\end{array}$ & 2011 & 2012 & 2013 & 2014 & 2015 \\
\hline e-Kancelaria & 1,570 & 6,339 & 6,747 & 7,924 & \\
\hline GC Investment & 4,991 & 3,049 & $-0,111$ & $-3,036$ & $-11,737$ \\
\hline Kopahaus & 1,361 & 2,706 & 3,388 & 4,643 & \\
\hline $\mathrm{PCZ}$ & 5,477 & 7,296 & 6,875 & 5,284 & 5,334 \\
\hline Uboat-Line SA & 2,557 & 5,200 & 5,529 & 2,721 & $-11,744$ \\
\hline
\end{tabular}


Tabela 1. cd. Wartości modeli dyskryminacyjnych ustalone dla emitentów obligacji korporacyjnych objętych badaniem

\begin{tabular}{|c|c|c|c|c|c|}
\hline $\begin{array}{l}\text { Rok } \\
\text { Spółka }\end{array}$ & 2011 & 2012 & 2013 & 2014 & 2015 \\
\hline e-Kancelaria & $-0,127$ & 3,164 & 3,526 & 2,389 & \\
\hline GC Investment & 1,100 & 0,789 & $-0,138$ & $-2,521$ & $-72,843$ \\
\hline Kopahaus & 2,347 & 1,684 & 0,292 & 1,061 & \\
\hline PCZ & $-0,105$ & 0,585 & 0,479 & 0,108 & 0,042 \\
\hline Uboat-Line SA & $-0,348$ & 2,123 & 1,537 & 0,387 & $-3,436$ \\
\hline \multicolumn{6}{|c|}{ MODEL E. ALTMANA } \\
\hline $\begin{array}{l}\text { Rok- } \\
\text { Spółka }\end{array}$ & 2011 & 2012 & 2013 & 2014 & 2015 \\
\hline e-Kancelaria & 5,318 & 8,917 & 8,946 & 8,689 & \\
\hline GC Investment & 7,202 & 6,318 & 2,556 & 1,087 & $-1,941$ \\
\hline Kopahaus & $-1,500$ & 1,431 & 3,569 & 5,971 & \\
\hline $\mathrm{PCZ}$ & 13,941 & 9,450 & 7,774 & 7,089 & 3,101 \\
\hline Uboat-Line SA & 5,918 & 8,527 & 7,852 & 6,176 & $-17,011$ \\
\hline
\end{tabular}

* Pogrubieniem oznaczono wyniki wskazujące na ryzyko upadłości

* Kolorem jasnoszarym oznaczono szarą strefę.

Źródło: opracowanie własne.

Wyniki uzyskane z przeprowadzonych analiz wskazują, że największą skutecznością (mierzoną liczbą wskazań zagrożenia upadłością emitenta obligacji korporacyjnych) charakteryzował się model opracowany przez B. Prusaka. Analizowany algorytm identyfikował ryzyko upadłości trzech jednostek - GC Investment, PCZ oraz Uboat-Line SA. W przypadku GC Investment oraz Uboat-Line SA wskazania były jednoznaczne, a symptomy pogarszającej się sytuacji finansowej obserwowane są na dwa (Uboat-Line SA) lub trzy (GC Investment) lata przed złożeniem wniosku o upadłość. Trzecia analizowana jednostka - spółka PCZ - mieściła się w przedziale szarej strefy, co sygnalizowało potencjalne zagrożenie upadłością.

Zbliżoną skutecznością charakteryzował się model E. Altmana, wedle którego ryzyko upadłości identyfikowane jest w odniesieniu do spółek GC Investment, PCZ oraz Uboat-Line SA. We wszystkich rozpatrywanych przypadkach obserwuje się sukcesywnie pogarszającą się sytuację finansową emitenta, w konsekwencji prowadzącą do upadłości. Należy jednak podkreślić, że symptomy rosnącego ryzyka niewypłacalności jednostki z odpowiednim wyprzedzeniem diagnozuje się wyłącznie w przypadku GC Investment - na 3 lata przed faktyczną upadłością. W pozostałych przypadkach - dopiero w roku upadłości.

Analizując rezultaty badania osiągnięte dla pozostałych modeli (D. Hadasik, E. Mączyńskiej i M. Zawadzkiego, D. Wierzby, poznańskiego) dostrzega się zgodność w zakresie oceny spółek GC Investment oraz Uboat-Line. Obaj emitenci w każdym z rozpatrywanych algorytmów klasyfikowani są jako jednostki narażone na ryzyko upadłości. W odniesieniu do trzech pozostałych obiektów wskazania są niejednoznaczne 
- sygnalizują o pogarszającej się sytuacji finansowej, nie klasyfikując przedsiębiorstwa do grona jednostek zagrożonych upadłością (np. PCZ), bądź identyfikują kondycję finansową emitenta jako dobrą (e-Kancelaria, Kopahaus).

\section{Zakończenie}

Przeprowadzona w ramach opracowania analiza wybranych modeli dyskryminacyjnych wskazuje, że mogą one stanowić cenne źródło informacji w procesach decyzyjnych. Odniesienie znanych i powszechnie wykorzystywanych metod oceny ryzyka upadłości przedsiębiorstw do specyficznego obiektu badań (jakim są emitenci obligacji korporacyjnych) pozwoliło stwierdzić, że spośród rozpatrywanych algorytmów największą skutecznością w zakresie właściwej klasyfikacji charakteryzował się model B. Prusaka oraz E. Altmana. Należy jednak podkreślić, że niewielka liczebność jednostek objętych badaniem utrudnia formułowanie jednoznacznych wniosków. Ponadto niewłaściwa klasyfikacja przedsiębiorstwa lub sprzeczne wskazania analizowanych algorytmów mają swe źródła w ich odmiennej konstrukcji, akcentującej różne obszary działalności jednostki. Brak skuteczności modeli dyskryminacyjnych może także wynikać z podłoża upadłości, niekoniecznie związanego $\mathrm{z}$ finansową sferą działalności przedsiębiorstwa. Uwzględniając oba uwypuklone aspekty, jak również specyfikę obiektu badań stwierdzić należy, że istnieje potrzeba budowy modeli umożliwiających identyfikację ryzyka upadłości emitentów obligacji korporacyjnych. Założenia konstrukcyjne metod dyskryminacyjnych zależą bowiem od specyficznych cech przedsiębiorstwa i otoczenia, w jakim ono funkcjonuje. Pomimo, że istniejące algorytmy analizy dyskryminacyjnej są narzędziami powszechnie stosowanymi to jednak należy pamiętać, że nie są one metodami uniwersalnymi. Podsumowując - modele dyskryminacyjne mogą okazać się szczególnie użyteczne dla obligatariuszy, stanowiąc jedną z metod oceny ryzyka utraty udostępnionego kapitału. Sukcesywne szacowanie modeli dyskryminacyjnych oraz analiza kierunku ich zmian może dostarczyć wartościowych spostrzeżeń w zakresie oceny kondycji finansowej emitenta długu. Warunkiem użyteczności analizowanych narzędzi jest jednak dostosowanie ich założeń konstrukcyjnych (koncepcyjnych) do obiektu badań.

\section{Bibliografia}

Altman E. I., Hotchkiss E.: Corporate Financial Distress and Bankruptcy. J. Wiley \& Sons, Inc. Hoboken, New Jersey 2006.

Gołębiowski G., Żywno K.: Weryfikacja skuteczności modeli dyskryminacyjnych na przykładzie wybranych spótek giełdowych, Współczesna Ekonomia, nr 3 (7), Warszawa 2008.

Hadasik D.: Upadtość przedsiębiorstw w Polsce. Metody jej prognozowania, Zeszyty Naukowe Seria II, Prace habilitacyjne, Zeszyt 153, Wydawnictwo Akademii Ekonomicznej w Poznaniu, Poznań 1998.

Hamrol M., Chodakowski J.: Prognozowanie zagrożenia finansowego przedsiębiorstwa. Wartość predykcyjna polskich modeli analizy dyskryminacyjnej, Badania Operacyjne i Decyzje, nr 3, Oficyna Wydawnicza Politechniki Wrocławskiej, Wrocław 2008.

Jagiełło R.: Analiza dyskryminacyjna i regresja logistyczna w procesie oceny zdolności kredytowej przedsiębiorstw, Materiały i Studia, Zeszyt 286, Narodowy Bank Polski, Warszawa 2013.

Korol T.: Systemy ostrzegania przedsiębiorstw przed ryzykiem upadłości, Oficyna Wydawnicza Wolters Kluwer Polska, Warszawa 2010. 
Kowalczyk S.: Przyczyny upadłości firm agrobiznesu, w: Meandry upadtości przedsiębiorstw. Klęska czy druga szansa?, Oficyna Wydawnicza Szkoły Głównej Handlowej, Warszawa 2009.

Mączyńska E., Zawadzki M.: Dyskryminacyjne modele predykcji upadłości przedsiębiorstw, „Ekonomista” nr 2/2006.

Pawłowski M.: Rynek obligacji korporacyjnych w Polsce. Uwarunkowania i perspektywy rozwoju, Cedewu, Warszawa 2015.

Prusak B.: Nowoczesne metody prognozowania zagrożenia finansowego przedsiębiorstw, Difin, Warszawa 2005.

Rogowski W.: Przyczyny upadłości przedsiębiorstwa w Polsce, Biuletyn Polskiego Towarzystwa Ekonomicznego, nr 1 (68), Warszawa 2015.

Ustawa z dnia 28 lutego 2003 r. Prawo upadlościowe, Dz.U. 2003, nr 60, poz. 535 z póżn. zm.

Wieczorek-Kosmala M.: Aplikacja instrumentów alternatywnego finansowania ryzyka (ARF) nowy wymiar retencji ryzyka $w$ przedsiębiorstwie, w: Ubezpieczenia gospodarcze i społeczne. Wybrane zagadnienia ekonomiczne, Oficyna Wydawnicza Wolters Kluwer Polska, Warszawa 2011.

Wierzba D.: Wczesne wykrywanie przedsiębiorstw zagrożonych upadtościa na podstawie wskaźników finansowych, Zeszyty Naukowe nr 9, Wydawnictwo Wyższej Szkoły EkonomicznoInformacyjnej w Warszawie, Warszawa 2000.

www.obligacje.pl, dostęp: 12.01.2018r.

Zielińska-Chmielewska A.: Zastosowanie analizy dyskryminacyjnej do oceny zagrożenia upadłościq polskich przedsiębiorstw przetwórstwa mięsnego, Studia Oeconomica Posnaniensia, vol. 3, no. 4, Wydawnictwo Uniwersytetu Ekonomicznego w Poznaniu, Poznań 2015.

\section{Summary}

The subject of the study is a verification of selected discriminatory models in assessing the bankruptcy risk of corporate bond issuers. This article discusses the essence of corporate bankruptcy and characterises a selected discriminatory models. Further more an empirical studies were carried out on a group of 5 companies representing corporate bond issuers listed on the Catalyst Bond Market. The analyze led to the conclusion that the B. Prusak's model was the most effective in identifying the bankruptcy risk of the corporate bond issuer.

Keywords: discriminatory models, enterprise bankruptcy, corporate bonds.

Informacja o autorze:

\section{dr Maciej Pawłowski}

Uniwersytet Szczeciński

Wydział Zarządzania i Ekonomiki Usług

Katedra Finansów Przedsiębiorstwa

e-mail: maciej.pawlowski@usz.edu.pl 